\title{
Occipital anaplastic oligodendroglioma with multiple organ metastases after a short clinical course: a case report and literature review
}

Gang Li ${ }^{1 \dagger}$, Zhiguo Zhang ${ }^{1 \dagger}$, Jianghong Zhang ${ }^{1 \dagger}$, Tianbo Jin², Hongjuan Liang ${ }^{1}$, Li Gong ${ }^{3}$, Guangbin Cui', Haixia Yang ${ }^{1}$, Shiming $\mathrm{He}^{1}$, Yongsheng Zhang ${ }^{5^{*}}$ and Guodong Gao ${ }^{1 *}$

\begin{abstract}
Background: It is generally believed that malignant gliomas never metastasize outside the central nervous system (CNS). However, the notion that oligodendrogliomas (OGDs) cells cannot spread outside CNS is being challenged.

Methods: We described in detail the clinical story of one patient with anaplastic OGD, which metastasized to lymph nodes, bone marrowand bones Genetic analyses included detection of $1 p$ and 19q chromosomal arms, methylation status of MGMT promoter, and PTEN exon mutations. A search of worldwide literature was conducted for reports of metastatic OGDs using NCBI-PubMed, with the keywords "extracranial", "extraneural", "oligodendroglioma", "oligodendrogliomas", "metastatic", "metastasis", and "metastases", in different combinations.

Results: An open biopsy of the infiltrated bones in our patient revealed that malignant cells had replaced the patient's marrow. Moreover, the diagnosis of multiple-organ metastases of anaplastic OGD was confirmed based on immunohistochemical staining. Genetic analyses showed that the tumors originated from previously resected brain lesions. None of the lesions had $1 p$ and 19q deletions, but hypermethylation of MGMT promoter, and the $G \rightarrow$ A transversion at codon 234 of PTEN exon 2 were detected. Literatures review yielded 60 reports of metastatic OGDs from 1951 to the present, which with our patient makes 61 cases. Concerning these 61 patients, there were 110 infiltrated sites correlated closely with primary OGDs. The most frequent metastatic sites were bone and bone marrow $(n=47 ; 42.7 \%)$, lymph nodes $(n=22 ; 20.0 \%)$, liver $(n=7 ; 6.4 \%)$, scalp $(n=6 ; 5.5 \%)$, lung $(n=6 ; 5.5 \%)$, pleura $(n=4$; $3.6 \%)$, chest wall $(n=3 ; 2.7 \%)$, iliopsoas muscle $(n=2 ; 1.8 \%)$, soft tissue $(n=2 ; 1.8 \%)$, and parotid gland $(n=2 ; 1.8 \%)$.
\end{abstract}

Conclusions: Extracranial metastases in anaplastic OGD are very rare but they do occur; bone and bone marrow may be the most common sites. Detection of certain molecular markers such as deletion of $1 p$ and $19 q$ chromosomal arms, hypermethylation of MGMT promoter, and characteristic PTEN exon mutations may help differentiate subtypes which are more prone to extracranial metastases.

Virtual slides: The virtual slide(s) for this article can be found here: http://www.diagnosticpathology.diagnomx.eu/vs/ 8749838611478560.

Keywords: Oligodendroglioma, Extracranial metastasis, Autopsy, 1p/19q, Chromosome deletions, Genetic analysis

\footnotetext{
* Correspondence: zhangys_td@163.com; gguodong@fmmu.edu.cn

${ }^{\dagger}$ Equal contributors

${ }^{5}$ Department of Administrative, Tangdu Hospital, Fourth Military Medical

University, Xi'an 710038, P.R. China

'Department of Neurosurgery, Tangdu Hospital, Fourth Military Medical

University, Xi'an 710038, P.R China

Full list of author information is available at the end of the article
}

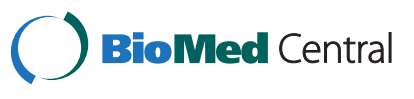

(C) 2014 Li et al.; licensee BioMed Central Ltd. This is an Open Access article distributed under the terms of the Creative Commons Attribution License (http://creativecommons.org/licenses/by/2.0), which permits unrestricted use, distribution, and reproduction in any medium, provided the original work is properly cited. The Creative Commons Public Domain Dedication waiver (http://creativecommons.org/publicdomain/zero/1.0/) applies to the data made available in this article, unless otherwise stated. 


\section{Background}

It has been widely believed by neurosurgeons and neurooncologists that malignant gliomas never metastasize outside the central nervous system (CNS) [1]. However, this notion has gradually proved incorrect. A review of 8000 tumors involving the CNS found only 35 cases of extracranial metastasis, including one oligodendroglioma (OGD) [2]. Liwnicz and Rubinstein [3] analyzed 116 cases in the literature and found that the most common metastasizing tumor type was glioblastoma multiforme (41.4\%) followed by medulloblastoma (26.7\%), ependymoma (16.4\%), and astrocytoma (10.3\%). and OGD (5.25\%) was the least common tumor type to metastasize $[3,4]$.

OGD is an uncommon diffuse glial tumor of central neuroepithelial origin, accounting for $\sim 4.2 \%$ of all primary brain tumors. It has been mostly identified in adults, with the highest incidence occurring in the fifth and sixth decades of life, although it has also been reported in children and adolescents [5]. Various forms of combination therapy administered as comprehensive treatment have improved the survival of patients with OGD or mixed oligoastrocytoma [6].

Herein, we report a case of anaplastic oligodendroglioma (AO) that metastasized to multiple lymph nodes, bone marrow, and bones, including the bilateral iliac bones, the right acetabulum, and multi-vertebral bodies.

\section{Case presentation}

A 45-year-old male who initially presented with a short history of headache and vomiting was admitted to our hospital in September 2011. No focal neurological deficit was found on admission. Magnetic resonance imaging (MRI) showed a left solid occipital tumor with mild contrast enhancing (Figure 1A,B,C). On 15 September 2011 he underwent a left solid occipital craniotomy with gross total resection confirmed by subsequent MRI scans (Figure 1D,E,F). The mass was yellow and friable. It was neither hemorrhagic nor necrotic. The tumor margin was ill defined. Photomicrographs of the resected tumor showed that there were higher cell densities, densely packed round cells with perinuclear haloes, microscopically round-tooblong cells with hyperchromatism and pleomorphism (Figure 2A-D), clusters of capillary or plexiform capillaries (Figure 2E,F), and obvious false fence structure-shaped necrosis (Figure 2G,H). In addition, the irregular mitosis densities were higher. A diagnosis was made of $\mathrm{AO}, \mathrm{WHO}$ (World Health Organization) grade III $[7,8]$. During the subsequent 6 months, he was given 4 cycles of adjuvant chemotherapy with temozolomide (TMZ; Schering, NJ), a standard regimen [9] of $150-200 \mathrm{mg} \cdot \mathrm{m}^{-2} \cdot \mathrm{d}^{-1}$ for 5 days, repeated every 28 days.

A repeated left occipital tumor resection was performed 8 months later (Figure 1G-L). Pathology also showed AO WHO grade III, with similar histology. Subsequently, irradiation therapy concomitant with TMZ, $75 \mathrm{mg} \cdot \mathrm{m}^{-2} \cdot \mathrm{d}^{-1}$ for 42 days, was given and then 3 cycles of adjuvant chemotherapy with a dose-intensive regimen of TMZ [10] of $75 \mathrm{mg} \cdot \mathrm{m}^{-2} \cdot \mathrm{d}^{-1}$ for 21 days, repeated every 28 days. The patient experienced no significant hematological toxicity, but he came to have difficulties in understanding and remembering.

In October 2012, 5 months after the final occipital resection, he presented with a 3-week history of lumbar and right hipbone pain, and was hospitalized again in November 2012. Regretfully, brain MRI showed evident progression of the intracranial lesion (Figure 1M-O). There was a solid enhancing lesion of high signal intensity on $\mathrm{T}_{2}$-weighted MR images, and low-intensity signals in the temporal area. The new lesion was thought to be a recurrent tumor with malignant transformation (Figure 1M-O). MR images of the spine showed diffuse patchy areas of increased signal intensity and abnormal enhancement of the T7, T10, T12, L2, L3, L5, and S1 vertebral bodies (Figure 1P,Q).

Subsequent bone scintigraphy and positron emission tomography (PET)-computed tomography (CT) scans revealed more multifocal invasion. A whole body ${ }^{99 \mathrm{~m}} \mathrm{Tc}$ methylene diphosphonate bone scan showed hyper-activity in the right iliac bone and the tenth and twelfth thoracic vertebral bodies (Figure 3). PET-CT scans also showed multifocal invasion of the bilateral iliac bones, the right acetabulum, the right femoral neck and the $\mathrm{C} 4, \mathrm{~T} 7, \mathrm{~T} 10$, T11, T12, L2, L3, and S1 vertebral bodies (Figure 4A,B), the lymph nodes at the left side of the eleventh thoracic vertebral body (Figure 4C) and the right supraclavicular region (Figure $4 \mathrm{D}$ ).

A bone marrow smear of the right iliac bone showed no plasmacytoma cells (Figure 5). An open biopsy of the infiltrated right iliac bone revealed the replacement of the patient's marrow by malignant cells, which exhibited nuclear pleomorphism (Figure 2I,J). The confirmed diagnosis of AO metastasis to bone marrow was based on immunohistochemical staining. We simultaneously reviewed and performed the tumor cell identification in the bone marrow spaces as well as in the previously primary $\mathrm{AO}$ in the brain. They were all strongly positive for isocitrate dehydrogenase-1 (IDH1; Figure 6A,B) and Ki-67, with proliferation index $>80 \%$ (Figure $6 \mathrm{C}$ ). They were also all positive for the glial fibrillary acidic protein (GFAP) marker (Figure 6D), which is positive in glial, Schwannian, and ependymal tumors (all neural tumors), and for the marker oligodendrocyte transcription factor (Oligo-2; Figure 6E). These findings supported the CNS origin of the metastatic cells. Further findings were all negative for other pertinent immunohistochemical stains: epithelial membrane antigen (EMA), O6- methylguanine-DNA methyltransferase (MGMT) and vimentin (Figure 6F,G,H, respectively). Multiple outside pathologists confirmed this diagnosis. 


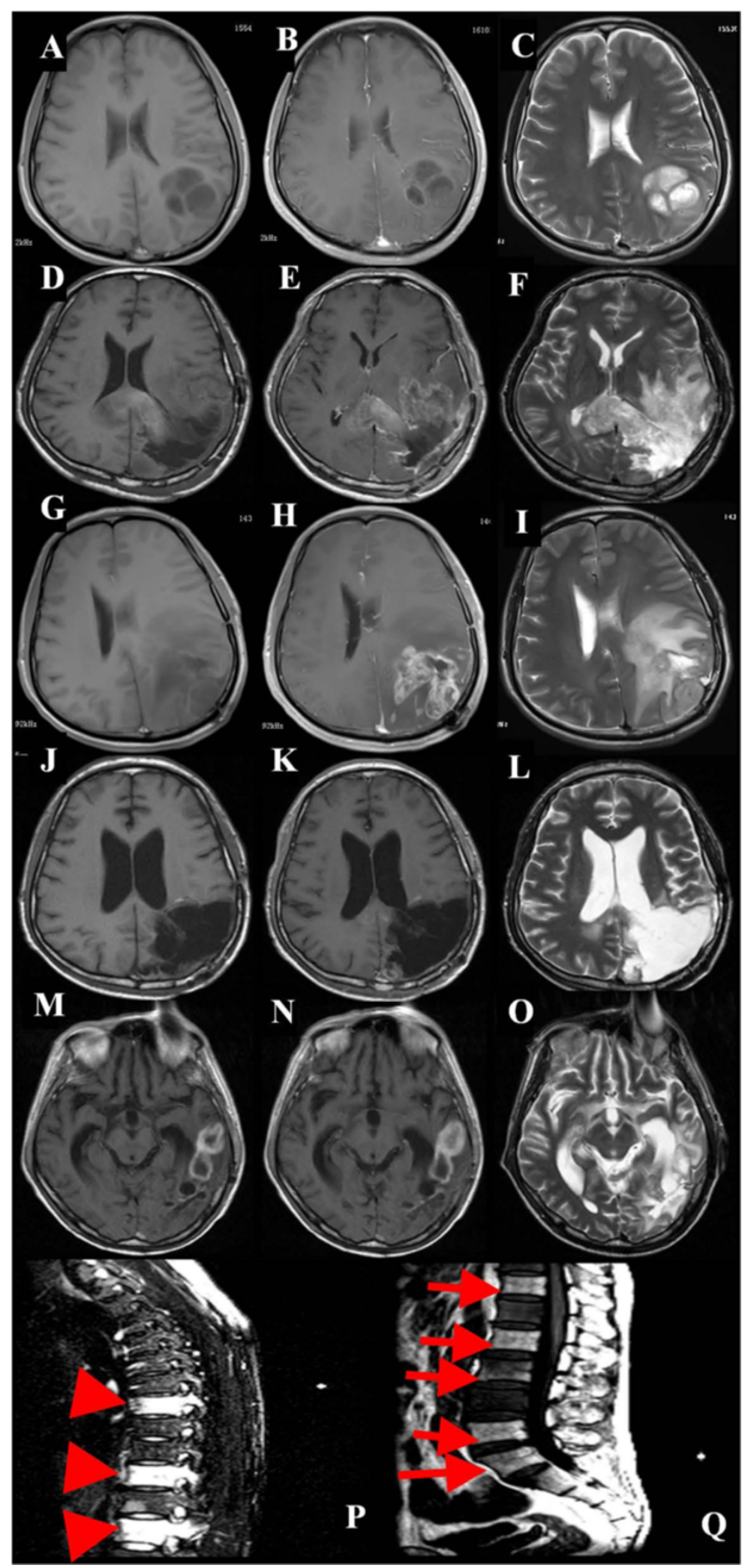

Figure 1 (See legend on next page.) 


\section{(See figure on previous page.)}

Figure 1 Representative axial MR images with gadolinium, taken on initial admission. (A) $T_{1}$-weighted MR image ( $\left.T_{1} W l\right)$; (B) Contrast-enhanced $T_{1} W$ l and $(C) T_{2}$-weighted MR image ( $T_{2}$ WI) showing a left occipital tumor with mild contrast enhancing; (D) at one month follow up, $T_{1} W l$; (E) contrast-enhanced $T_{1} W l$ and (F) $T_{2} W l$ showing no apparent enhanced lesion; (G) 8 months later after the first surgery, $T_{1} W l ;(\mathbf{H})$ contrast-enhanced $\mathrm{T}_{1} \mathrm{Wl}$ and (I) $\mathrm{T}_{2} \mathrm{Wl}$ showing marked enhanced mass on the cavity and recurrence; $(\mathbf{J}) 48 \mathrm{~h}$ after the second surgery, $\mathrm{T}_{1} \mathrm{Wl} ;(\mathbf{K})$ contrast-enhanced $\mathrm{T}_{1} \mathrm{WI}$, and (L) $T_{2} W l$ showing no apparent enhanced lesion; (M) 8 months later after combination radiotherapy and chemotherapy, $T_{1} W l ;(N)$ contrast-enhanced $\mathrm{T}_{1} \mathrm{Wl}$ and $(\mathbf{O}) \mathrm{T}_{2} \mathrm{Wl}$ showing marked enhanced mass of the wall in the posterior portion of the removal cavity and left temporal areas, and recurrence of the enhanced tumor. $(\mathbf{P}, \mathbf{Q}) 8$ months later after combination radiotherapy and chemotherapy, sagittal spinal contrast-enhanced $T_{1} W \mathrm{~W}$ after gadolinium infusion showing high-intensity mass lesion in (P) T7, T10, and T12 vertebral bodies (arrowheads) and (Q) T12, L2, L3, L5, and S1 vertebral bodies (arrows).

After discussion with the patient and his family, he was admitted to the family ward and supportive care was administered until his death on 19 January 2013.

\section{Materials and methods}

\section{Tissue samples}

We collected and analyzed both the bone marrow from the above mentioned open biopsy and the brain tumor tissues resected in the first and second craniotomy. The Human Research Committee of the Fourth Military Medical University approved the use of human tissues, in accordance with the Approval of Research Involving Human Subjects. The patient's custodians provided informed written consent. All specimens were handled and made anonymous in accordance with ethical and legal standards.

\section{DNA extraction}

The bone marrow from the biopsy was decalcified using ultrasonic decalcification with ethylenediaminetetraacetic acid (EDTA) as described previously [11] and paraffin embedded. DNA was extracted from the tumor tissues as previously described $[12,13]$. In brief, DNA was isolated by sodium dodecyl sulfate/proteinase $\mathrm{K}$ treatment, phenol-chloroform extraction, and ethanol precipitation and then dissolved and stored in $1 \times$ Tris-EDTA (TE) buffer. DNA concentration was measured at optical density 260 $\left(\mathrm{OD}_{260}\right)$, and purity was verified by $\mathrm{OD}_{260} / \mathrm{OD}_{280} \approx 1.8$.

\section{Fluorescent in situ hybridization (FISH) assay}

Sections from the brain tumors and metastatic lesions were evaluated with routine hematoxylin-eosin ( $\mathrm{H} \& \mathrm{E})$ staining. FISH assays were also performed for molecular characterization. Both the brain tumors and the metastatic lesions were analyzed to perform dual-color FISH assay as previously published [14]. Briefly, paired probes for 1p36/1q25-q31 and 19q13/19p12 (Abbott Molecular) were prepared [14]. Green and red fluorescent signals were enumerated under a Leica microscope with appropriate filters. For each hybridization, a minimum of 40 non-overlapping nuclei were assessed for numbers of green and red signals, counted separately by two individuals.

\section{MGMT promoter methylation status}

DNA from the tumor tissues was analyzed by performing a methylation-specific polymerase chain reaction (MS-PCR) assay, as previously published [15], to detect the status of the MGMT promoter.

PCR single-strand conformation polymorphism (PCR-SSCP) and DNA sequencing for phosphatase and tensin homologue (PTEN) deleted on chromosome ten exons

PCR-SSCP assay was applied to elucidate the mutations in exons 1-9 of the PTEN gene (Table 1) [16-18]. PCR amplification was carried out in a final volume of $25 \mu \mathrm{L}$ containing $50 \mathrm{ng}$ DNA, $2.5 \mu \mathrm{L}$ of $10 \times$ PCR buffer, $1.5 \mathrm{mmol} / \mathrm{L} \mathrm{MgCl}_{2}, 10 \mathrm{pmol} / \mathrm{L}$ of each primer, $2.5 \mathrm{mmol} / \mathrm{L}$ of each dNTP, and $1 \mathrm{U}$ Taq DNA polymerase. The amplification conditions were: an initial incubation at $95^{\circ} \mathrm{C}$ for $8 \mathrm{~min} ; 35$ cycles at $95^{\circ} \mathrm{C}$ for $30 \mathrm{~s}, 51-57^{\circ} \mathrm{C}$ for $45 \mathrm{~s}$ for each primer specific to the PTEN exons (Table 1 ), and $72^{\circ} \mathrm{C}$ for $30 \mathrm{~s}$; with a final extension at $72^{\circ} \mathrm{C}$ for $7 \mathrm{~min}$. PCR products were resolved in $2 \%$ agarose gels stained with ethidium bromide with a 100-bp DNA ladder as a standard reference, and electrophoresed for $30 \mathrm{~min}$ at $100 \mathrm{~V}$.

SSCP analyses of all PTEN exons were conducted systematically on the PCR products. Equal volumes $(7 \mu \mathrm{L})$ of the PCR products and loading buffer (95\% formamide, $20 \mathrm{mM}$ EDTA, $0.05 \%$ bromphenol blue, and $0.05 \% \mathrm{xy}-$ lene cyanol) were mixed and centrifuged for $15 \mathrm{~s}$, heatdenatured at $95^{\circ} \mathrm{C}$ for $7 \mathrm{~min}$, snap-chilled on ice for $10 \mathrm{~min}$, and resolved through an $8 \%$ non-denaturing polyacrylamide gel (acrylamide to bisacrylamide, 29:1) containing $50 \mathrm{mM}$ Tris-borate $(\mathrm{pH} 7.5)$ and $2.5 \mathrm{mM}$ EDTA, and electrophoresed with $1 \times$ tris-borate-EDTA buffer for $16 \mathrm{~h}$ at $14^{\circ} \mathrm{C}$ at a voltage of $100 \mathrm{~V}$. Silver staining was performed as previously described [19].

According to the PCR-SSCP results of genomic DNA, the present sample was considered PCR-SSCP positive based on the evident difference in the single strand strip number and electrophoresis transference location [20]. Genomic DNA from the positive PCR-SSCP sample was amplified again in a $40-\mu \mathrm{L}$ reaction system for bidirectional DNA sequencing. The amplified PCR products were sequenced with an ABI PRISM 310 dye terminator cycle sequencing ready reaction kit. The results were compared using the GenBank database. 

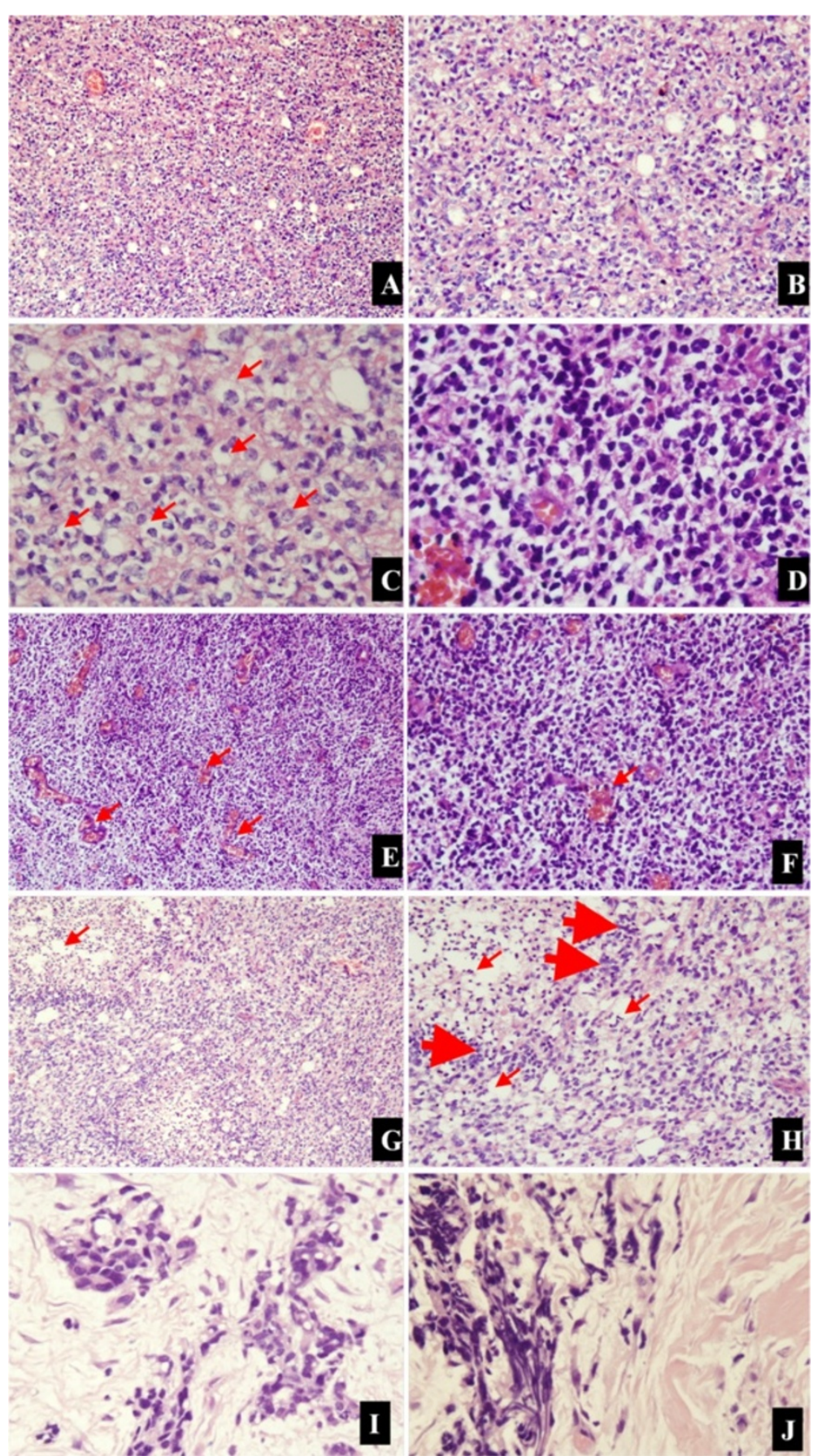

Figure 2 Representative photomicrographs of the tumor specimens. Higher cell densities (A, B; 100X, 200x, respectively, H \& E) with perinuclear haloes (C; 200X, H \& E; arrows), and microscopically round-to-oblong cells with hyperchromatism and pleomorphism (D; 400X, H \& E), are compatible with AO. (E, F) Clusters of capillary or plexiform capillaries (arrows), and the irregular mitosis densities were higher (100X, 200X, respectively, H \& E). (G, H) Obvious false fence structure (thick arrows)-shaped necrosis (slim arrows; 100x, 200x, respectively, H \& E). (I, J) After the right iliac bone marrow needle biopsy, cells in the bone marrow specimen from the patient were small and round with a thin rim of eosinophilic cytoplasm (400X, H \& E).

\section{Results}

\section{FISH analysis}

None of the tumors from the resected brain lesions or the metastatic lesions had the $1 \mathrm{p}$ (Figure $7 \mathrm{~A}$ ) or 19q deletions
(Figure 7B). We were satisfied that, although the bone marrow from the biopsy was decalcified via ultrasonic decalcification and EDTA, the metastatic lesions remained informative. 


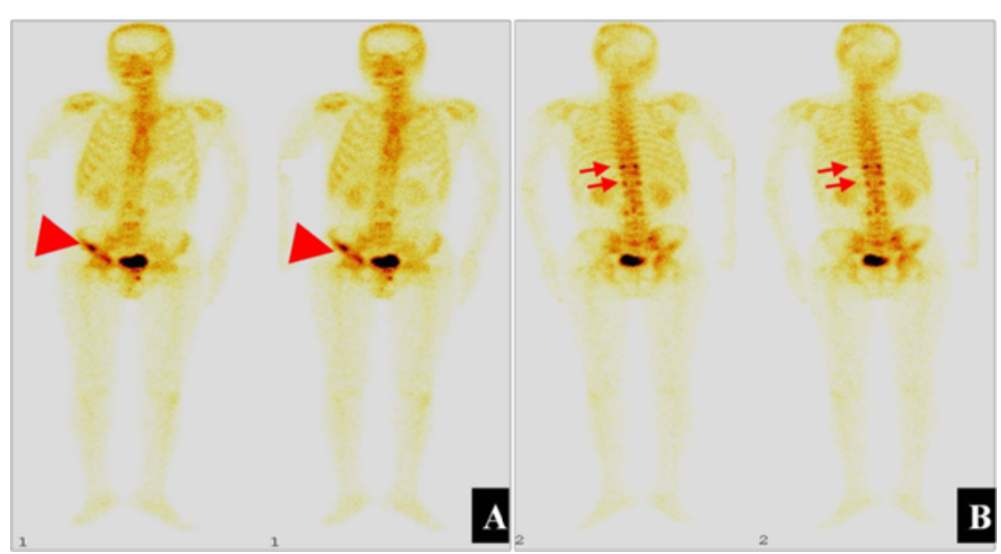

Figure 3 Representative emission computed tomography scans. (A) anterior scans, and (B) posterior scans, showed a hypermetabolically abnormal uptake at the right iliac bone (arrowheads) and T10, and T12 vertebral bodies (arrows).

\section{Methylation status of the MGMT promoter}

The MSP-PCR assays of the tumors from the primary brain lesions and autopsied metastasized tissues all showed the methylated MGMT promoter (Figure 8), and the result from the corresponding samples was nearly identical.

\section{PTEN mutation}

The case was considered PCR-SSCP-positive, and genomic DNA from the samples was amplified for bidirectional DNA sequencing. Compared with the sequences in the GenBank database, the sequencing data of the patient showed a transversion, "A" in place of "G" at codon 234

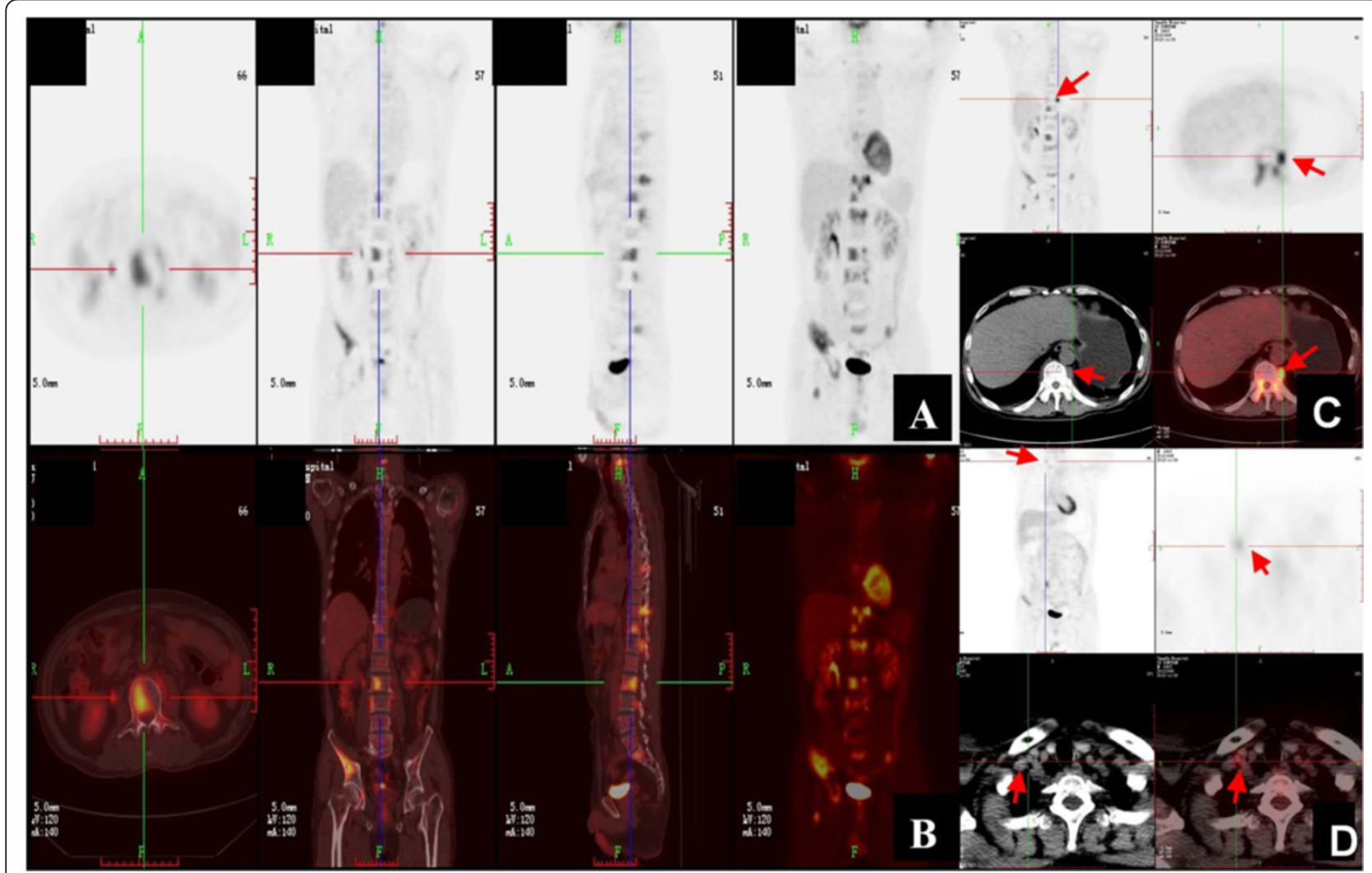

Figure 4 Representative whole body PET-CT scans. (A) and (B) Multiple foci of increased 18 F-fluoro-2-deoxyglucose (FDG) uptake at the bilateral iliac bones, C4, T7, T11, T10, T12, L2, L3, S1 vertebral bodies and the right acetabulum; (C) Focus of increased ${ }^{18}$ F-FDG uptake at the lymph node near the left side of the T11 vertebral body (arrows); (D) Focus of increased ${ }^{18}$ F-FDG uptake at the lymph node of the right supraclavicular region (arrows). 


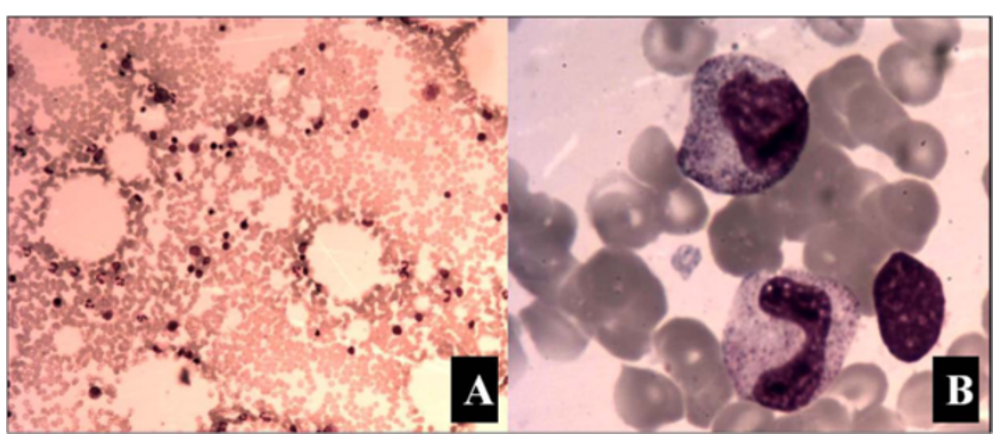

Figure 5 Representative scans of bone marrow smear. (A, B) No plasmocytoma cells were found (100x and 1000x, respectively).
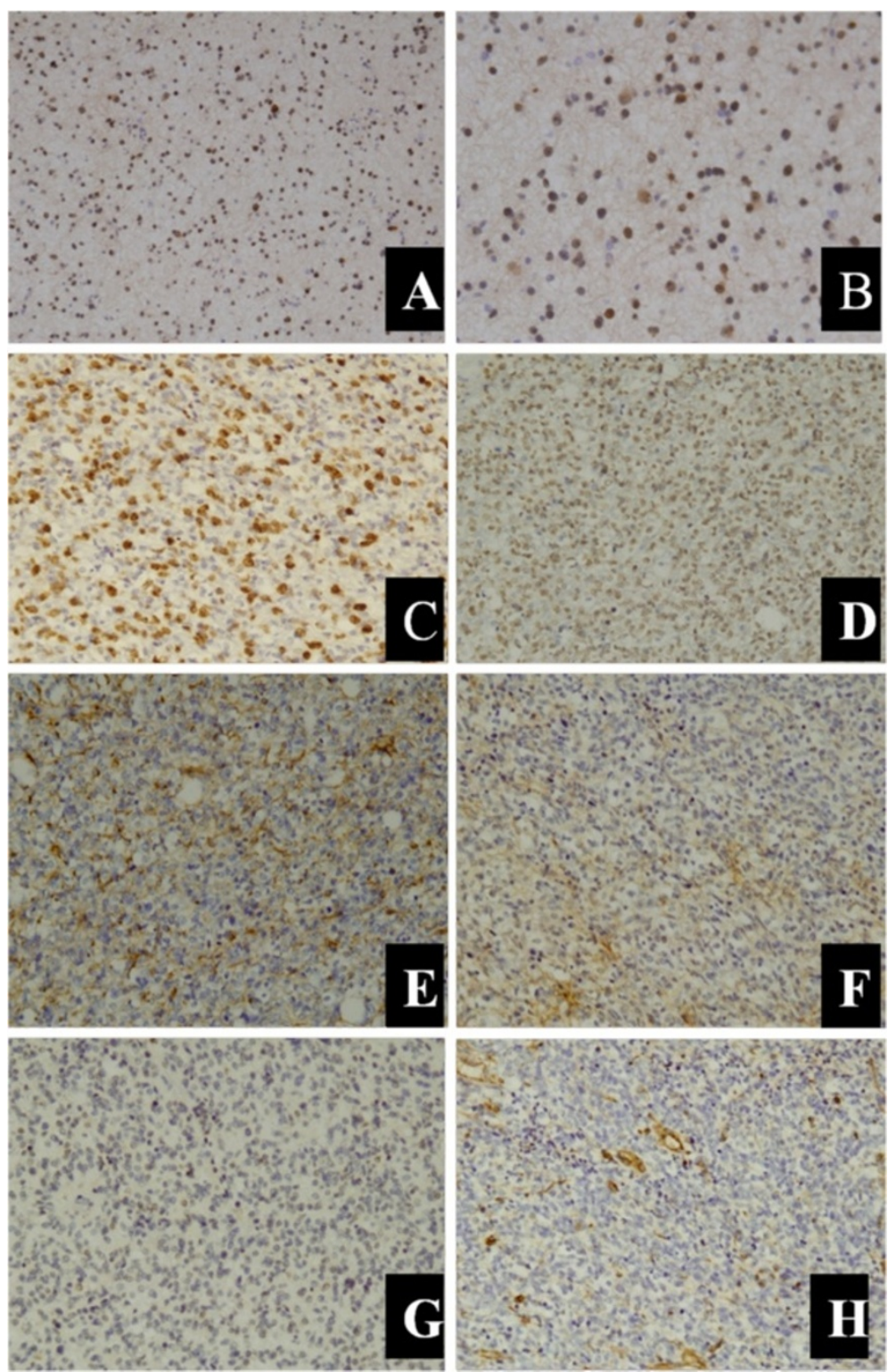

Figure 6 Representative immunochemical markers in tumor specimens. (A, B) Positive reaction for IDH1 (100x, 200x, respectively). (C) Positive reaction for Ki-67, with proliferating index $>80 \%$ (200X). (D, E) Tumor cells were positive for GFAP and Oligo-2, respectively (200X). $(\mathbf{F}, \mathbf{G}, \mathbf{H})$ showed the tumor cells were negative for EMA, MGMT, and vimentin, respectively (200X). 
Table 1 PTEN primers used for single-strand conformation polymorphism (SSCP) analysis

\begin{tabular}{|c|c|c|c|}
\hline Exon & Primer sequences & $\begin{array}{l}\text { Annealing } \\
\text { temp. }\left({ }^{\circ} \mathrm{C}\right)\end{array}$ & $\begin{array}{c}\text { Amplicon } \\
\text { (bp) }\end{array}$ \\
\hline \multirow[t]{2}{*}{1} & F1. 5'-TCCTCCTTTTCTTCAGCCAC-3' & 56 & 147 \\
\hline & R1. 5'-GAAAGGTAAAGAGGAGCAGCC-3' & & \\
\hline \multirow[t]{2}{*}{2} & F2. 5'-TGCATATTTCAGATATTTCTTTCCTT-3' & 57 & 155 \\
\hline & R2. 5'-TTTGAAATAGAAAATCAAAGCATTC-3' & & \\
\hline \multirow[t]{2}{*}{3} & F3. 5'-TGTTAATGGTGGCTTITTG-3' & 56 & 114 \\
\hline & R3. 5'-GCAAGCATACAAATAAGAAAAC-3' & & \\
\hline \multirow[t]{2}{*}{4} & F4. 5'-TTCCTAAGTGCAAAAGATAAC-3' & 56 & 147 \\
\hline & R4. 5'-TACAGTCTATCGGGTTTAAGT-3' & & \\
\hline \multirow[t]{2}{*}{5} & F5. 5'-TाTाTाTाCTATTCTGAGGTTATC-3' & 51 & 312 \\
\hline & R5. 5'-GAAGAGGAAAGGAAAAACATC-3' & & \\
\hline \multirow[t]{2}{*}{6} & F6. 5'-AGTGAAATAACTATAATGGAACA-3' & 54 & 231 \\
\hline & R6. 5'-GAAGGATGAGAATTTCAAGC-3' & & \\
\hline \multirow[t]{2}{*}{7} & F7. 5'-ATCGTTITTGACAGTTTG-3' & 55 & 262 \\
\hline & R7. 5'-TCCCAATGAAAGTAAAGTAGA-3' & & \\
\hline \multirow[t]{2}{*}{8} & F8. 5'-AGGTGACAGATTTCTTITTIA-3' & 52 & 394 \\
\hline & R8. 5'-TAGCTGTACTCCTAGAATTA-3' & & \\
\hline \multirow[t]{2}{*}{9} & F9. 5'-CTTTCTCTAGGTFAAGCTGTACTT-3' & 55 & 231 \\
\hline & R9. 5'-TTCATGGTGTTTTATCCCTCTTGA-3' & & \\
\hline
\end{tabular}

of exon 2. This was thought to be a likely single nucleotide polymorphism (Figure 9). No mutation was detected in the other PTEN exons.

\section{Discussion}

Extraneural metastases from primary brain tumors are rare [21] for reasons that remain obscure. Proposed initial theories generally lack credibility among neurosurgeons and neurooncologists; these include collapse of thin-walled cerebral veins, the inability of neural tissue to grow outside the CNS, and the lack of lymphatics in the brain [22]. More accepted is the theory that because brain tumors present earlier, there is less time for metastases to develop [21]. Another theory suggests that the intracerebral environment is not sufficiently hostile to select out metastatic clones. There is relatively little connective tissue stroma in the brain compared with the rest of the body. It has also been proposed that clones are not selected for the ability to invade fibrous connective tissue and are thus not suited to invade extracranial tissues [23]. The role of the bloodbrain barrier is also uncertain, albeit it does seem to have a limited role in metastasis.

Despite the above theories, glioma does metastasize outside the CNS, and most cases of extraneural metastasis (nearly 96\%) have occurred after surgical excision of the primary tumor [24]. The most common glioma to metastasize is glioblastoma multiforme, followed by medulloblastoma and ependymoma [4], while OGD metastasizes very rarely.

OGD is such a diffuse glial tumor. Extracranial metastasis of the primary intracranial neoplasm is infrequent generally, and it seemed to usually happen only in the setting of prior neurosurgical resection [25]. OGDs are characterized by multiple recurrences [25], extraneural spread is unusual, and distant skeletal metastases are particularly infrequent. We therefore undertook a worldwide literature review to investigate further the incidence of extraneural metastases. This yielded 60 previously reported metastatic OGDs from 1951 to the present, and our patient makes 61 (Table 2). The review was performed using NCBI-PubMed with the keywords "extracranial", "extraneural", "oligodendroglioma", "oligodendrogliomas", "metastatic", "metastasis", and "metastases" in different combinations. We also reviewed the bibliography of the subsequently selected articles.

Of the 61 reported metastatic OGDs, 33 (54.1\%) were male, 17 (27.9\%) were female, and in the remaining cases $18.0 \%$ gender was not reported (Table 3). Ten (16.4\%) patients were Asian, 30 (49.2\%) were European, 18 (29.5\%)

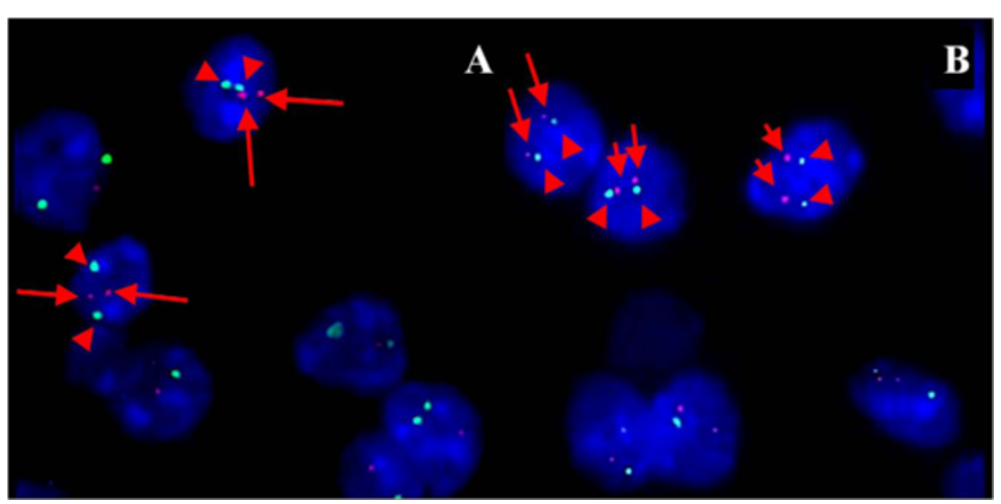

Figure 7 Representative FISH images from the right iliac bone. Some signals are missing due to nuclear truncation. (A) No $1 p$ deletion, with 2 red (1p36, arrows) and 2 green (1q25-q31, arrowheads) signals in scattered nuclei. (B) No 19q deletion with 2 red (19q13, arrows) and 2 green (19p12, arrowheads) signals in scattered nuclei. 


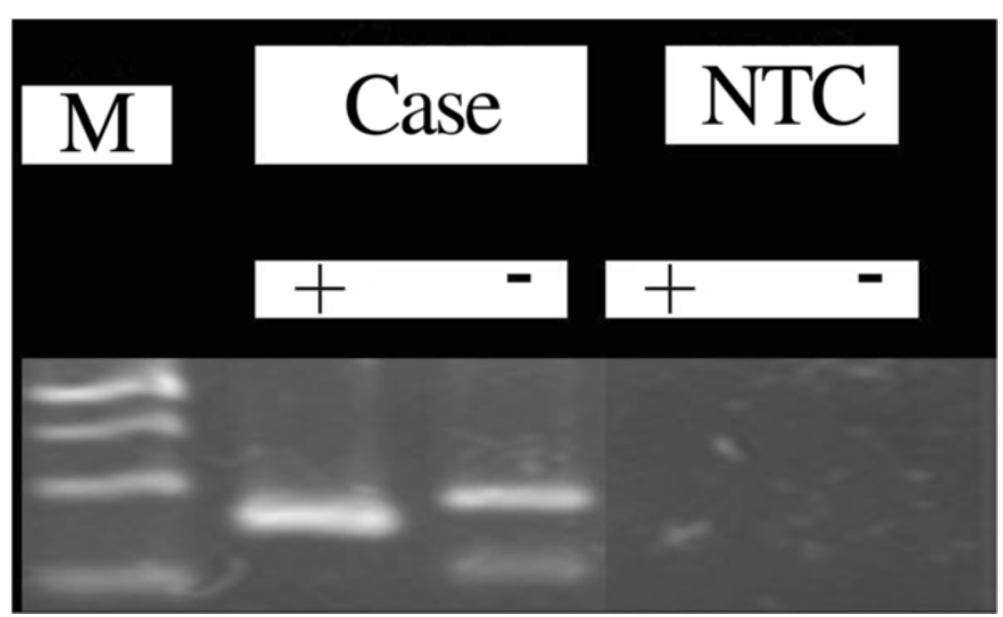

Figure 8 Representative MSP-PCR for methylated MGMT promoter. NTC, non DNA template control; +, methylated; -, unmethylated; M, DNA marker; the upper, middle, and lower bands are 140, 120, 100, and 80 bp, respectively.

were American or Canadian, and for the remaining 3 $(4.9 \%)$ the ethnicities were unreported. There were 110 infiltrated sites correlated closely with primary OGDs. The most frequent metastatic site was bone and bone marrow $(n=47 ; 42.7 \%)$ followed by lymph nodes $(n=22 ; 20.0 \%)$, liver $(n=7 ; 6.4 \%)$, scalp $(n=6 ; 5.5 \%)$, lung $(n=6 ; 5.5 \%)$, pleura $(n=4 ; 3.6 \%)$, chest wall $(n=3 ; 2.7 \%)$, iliopsoas muscle $(n=2 ; 1.8 \%)$, soft tissue $(n=2 ; 1.8 \%)$, parotid gland $(n=2 ; 1.8 \%)$, and adrenal gland, spleen, thoracic wall, pancreas, dorsal root ganglia, abdomen, spinal dura mater, breast, and thymus gland with one lesion each $(n=1 ; 0.9 \%)$.

The review indicated that bone and bone marrow are the most common sites metastasizing from OGDs. In our present case, systematic examination found multiple extracranial metastases, including the vertebrae, lymph nodes, bilateral iliac bones, and right acetabulum. Metastases in these sites suggest that tumor cells were delivered via the blood vessels and lymphatic system.
Primary neoplasm in the brain is generally considered to spread in any of three ways: seeding through the cerebral fluid pathway, local invasion, or spreading remotely through lymphatic and blood vessels [68]. It is widely accepted that the brain and spinal cord contain no lymphatic pathway. However, as the tumor cells infiltrate the dura mater, extracranial metastasis by way of the lymphatic system becomes possible, and could especially happen after craniotomy. Surgical procedures can elevate the risk of metastasis outside the nervous system by way of the lymphatic system as well as the blood vessel.

Extraneural metastasis is considered correlated with multiple craniotomies, shunt surgery, and long-term survival $[39,69,70]$. Extracranial metastasis without previous surgical intervention is infrequent; among 282 reported cases of glioma with metastases outside the CNS only 24 (8.5\%) were spontaneous [71]. Most cases of extracranial metastasis occur after craniotomy. Shunt surgery is responsible for seeding tumor cells by way of cerebrospinal

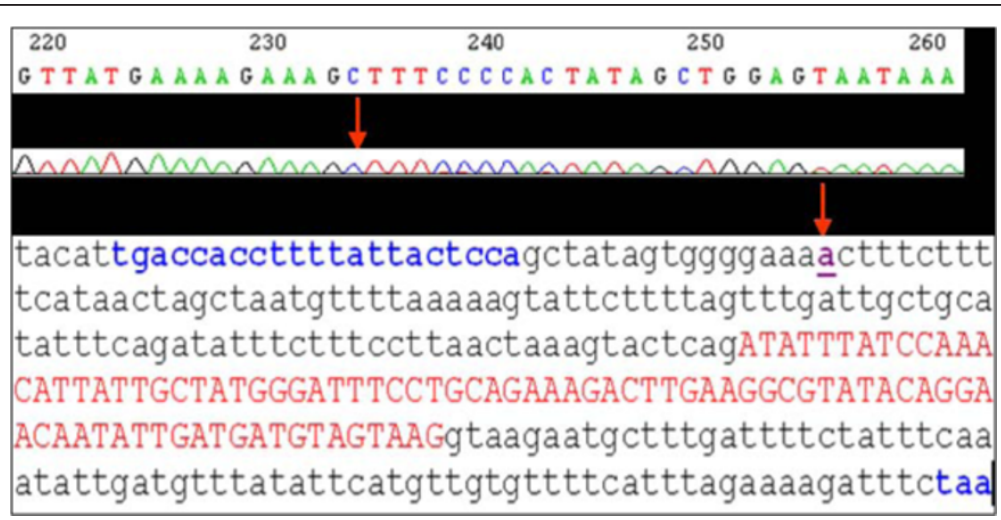

Figure 9 Representative sequencing data showing the $\mathrm{G} \rightarrow \mathrm{A}$ transversion at codon 234 (arrows) of exon 2 in PTEN of the patient. Blue, primer; red, exon 2; purple, the transversion of $\mathrm{A}$, showing the polymorphism. 
Table 2 Review from the literature of 61 reported patients with oligodendroglioma with metastases outside the CNS

\begin{tabular}{|c|c|c|c|c|c|c|c|c|c|}
\hline Patient no. & Gender & Subjects & WHO grade & $\begin{array}{l}\text { Age at } \\
\text { diagnosis }(y)\end{array}$ & Location of metastasis & OS (months) & $\begin{array}{l}\text { Time between } \\
\text { presentation of } \\
\text { primary tumor and } \\
\text { metastasis (months) }\end{array}$ & $\begin{array}{l}\text { Molecular biomarkers } \\
\text { tested }\end{array}$ & Reference \\
\hline 1 & $\mathrm{~F}$ & British & $\begin{array}{l}\text { ODG, low grade early, } \\
\text { later *AO }\end{array}$ & 25 & $\begin{array}{l}\text { Cervical lymph nodes, scalp, } \\
\text { lung, bone }\end{array}$ & 84 & * & * & James et al. 1951 [26] \\
\hline 2 & $\mathrm{~F}$ & American & ODG, *grade & 7 & Scalp, bone, soft tissue, liver & 36 & * & * & Spataro et al. 1968 [27] \\
\hline 3 & $\mathrm{~F}$ & Austrian & ODG, * grade & 58 & Bone & 30 & $*$ & * & $\begin{array}{l}\text { Jellinger et al. } 1969 \text { [28], } \\
\text { (also reported as } \\
\text { Schuster et al. } 1976 \text { [29]) }\end{array}$ \\
\hline 4 & M & American & ${ }^{*} \mathrm{ODG},{ }^{*}$ grade & 45 & Bone marrow & 17 & * & * & Smith et al. 1969 [2] \\
\hline 5 & * & * & ODG, initially low grade & 3.5 & Lymph nodes, lungs, adrenal & 21 & * & * & Kernohan 1971 [30] \\
\hline 6 & $\mathrm{~F}$ & Scottish & $\begin{array}{l}\text { Malignant glioma, some } \\
\text { ODG features }\end{array}$ & 21 & Bone & 9 & * & $*$ & Eade et al. 1971 [31] \\
\hline 7 & M & Scottish & $\begin{array}{l}\text { Small cell GBM with } \\
\text { regions of ODG }\end{array}$ & 23 & Bone & 12 & * & * & \\
\hline 8 & M & French & ${ }^{*} \mathrm{ODG},{ }^{*}$ grade & 57 & Lymph nodes, bone & 20 & * & * & $\begin{array}{l}\text { Cappellaere et al. } \\
1972 \text { [32] }\end{array}$ \\
\hline 9 & M & French & ${ }^{*} \mathrm{ODG},{ }^{*}$ grade & 22 & $\begin{array}{l}\text { Lymph nodes, bone, parotid } \\
\text { gland }\end{array}$ & 25 & * & * & \\
\hline 10 & $\mathrm{~F}$ & British & $\begin{array}{l}\text { Malignant glioma, some } \\
\text { ODG features }\end{array}$ & 30 & Pleura & 156 & * & * & Brander et al. 1975 [33] \\
\hline 11 & M & German & ${ }^{*} \mathrm{ODG},{ }^{*}$ grade & 40 & Bone, lymph nodes, lungs & 86 & * & * & Kummer et al. 1977 [34] \\
\hline 12 & * & Canadian & ${ }^{*} \mathrm{ODG},{ }^{*}$ grade & * & Scalp & * & * & * & Chin et al. 1980 [35] \\
\hline 13 & $\mathrm{~F}$ & American & ODG, grade ॥ & 33 & $\begin{array}{l}\text { Bone, lymph nodes, scalp, } \\
\text { soft tissue }\end{array}$ & 50 & * & * & Ordonez et al. 1981 [36] \\
\hline 14 & M & Japanese & Grade III & 32 & Bone & 76 & 14 & * & Nakamura et al. 1985 [37] \\
\hline 15 & M & * & ODG, malignant & 41 & Bone marrow & 48 & * & * & Newman et al. 1985 [38] \\
\hline 16 & * & Canadian & $\begin{array}{l}\text { ODG, * grade, } \\
\text { some astro }\end{array}$ & 12 & Bone, lymph nodes, scalp & 104 & * & * & Macdonald et al. 1989 [39] \\
\hline 17 & * & Canadian & ODG, * grade & 44 & Cervical lymph nodes, bone, & 48 & * & * & \\
\hline 18 & $\mathrm{~F}$ & Canadian & ODG, grade III & 36 & Bone, lymph nodes & 60 & * & * & \\
\hline 19 & * & Canadian & $\begin{array}{l}\text { ODG, * grade, } \\
\text { some astro }\end{array}$ & 32 & Bone, lymph nodes, scalp & 38 & * & * & \\
\hline 20 & * & Canadian & ODG, * grade & 34 & Bone & $76+$ & * & * & \\
\hline 21 & M & Canadian & ODG, grade III & 27 & Bone & 37 & * & * & \\
\hline 22 & * & Canadian & $\begin{array}{l}\text { ODG, * grade, } \\
\text { some astro }\end{array}$ & 47 & Bone & $26+$ & * & * & \\
\hline 23 & * & Polish & Grade III & * & * & * & * & * & Rolski et al. 1993 [40] \\
\hline
\end{tabular}


Table 2 Review from the literature of 61 reported patients with oligodendroglioma with metastases outside the CNS (Continued)

\begin{tabular}{|c|c|c|c|c|c|c|c|c|c|}
\hline 24 & * & German & * & * & Cervical lymph nodes & * & * & $*$ & Steininger et al. 1993 [41] \\
\hline 25 & M & British & ODG, grade III & 54 & Bone marrow & 12 & * & * & Gerrard et al. 1995 [42] \\
\hline 26 & * & German & Grade III & * & Cervical lymph nodes & * & 48 & * & Schroder et al. 1995 [43] \\
\hline 27 & M & Italian & ODG, grade II & 58 & $\begin{array}{l}\text { Chest wall, bone marrow, } \\
\text { possibly liver }\end{array}$ & 48 & * & * & Monzani et al. 1996 [44] \\
\hline 28 & M & British & ODG, grade III & 43 & Bone marrow, liver & 3 & * & * & Dawson 1997 [45] \\
\hline 29 & M & Austrian & $\begin{array}{l}\text { ODG-astrocytoma } \\
\text { grade III }\end{array}$ & 62 & $\begin{array}{l}\text { Thoracic wall, pleura, bone } \\
\text { marrow }\end{array}$ & 288 & 6 & * & Finsterer et al. 1998 [46] \\
\hline 30 & M & Indian & Grade III & 50 & Bone and bone marrow & $7+$ & * & * & Anand et al. 2001 [47] \\
\hline 31 & * & Italian & ODG, grade II & 25 & Bone & $84+$ & * & * & Giordana et al. 2002 [48] \\
\hline 32 & M & Indian & Grade III & 50 & Bone marrow & 17 & * & * & Sharma et al. 2003 [49] \\
\hline 33 & M & American & Grade III & 33 & Bone marrow & $38+$ & * & * & Choon et al. 2004 [50] \\
\hline 34 & M & Canadian & Grade III & 35 & Bone & 84 & 23 & $\begin{array}{l}\text { Allelic LOH of chromosome } 1 p \\
(1 p-) \text {, a rise in serum alkaline } \\
\text { phosphatase }\end{array}$ & Morrison et al. 2004 [51] \\
\hline 35 & $\mathrm{~F}$ & American & $\begin{array}{l}\text { ODG, grade II early, } \\
\text { later AO, grade III }\end{array}$ & 41 & Parotid gland & $79+$ & 68 & Codeletion of $1 p / 19 q$ & Wang et al. 2004 [52] \\
\hline 36 & M & American & $\begin{array}{l}\text { ODG, low grade early, } \\
\text { later } \mathrm{AO} \text {, grade III }\end{array}$ & 28 & Bone marrow & 120 & 5 & $\begin{array}{l}\text { Positive for S-100 marker with } \\
\text { immunohistochemical stain }\end{array}$ & Al-Ali et al. 2005 [23] \\
\hline 37 & M & American & $\begin{array}{l}\text { Atypical meningioma, } \\
\text { early, later } \mathrm{AO} \text {, grade III }\end{array}$ & 32 & $\begin{array}{l}\text { Bone, bone marrow, cervical } \\
\text { and thoracic lesions }\end{array}$ & 168 & 27 & $\begin{array}{l}\text { Elevated serum lactate } \\
\text { dehydrogenase and alkaline } \\
\text { phosphatase, positive for } \\
\text { S-100, and GFAP with } \\
\text { immunohistochemical stain }\end{array}$ & Merrell et al. 2006 [53] \\
\hline 38 & $\mathrm{~F}$ & American & $\mathrm{AO}$, grade III & 71 & Bone, bone marrow, & 17 & 13 & $\begin{array}{l}\text { Codeletion of } 1 \mathrm{p} / 19 \mathrm{q} \text {, positive } \\
\text { for } \mathrm{S}-100 \text {, and GFAP with } \\
\text { immunohistochemical stain, } \\
\text { elevated serum hemoglobin level }\end{array}$ & \\
\hline 39 & $\mathrm{~F}$ & Chinese & ODG, * grade & 64 & Pleura, bone & $*$ & 84 & $\begin{array}{l}\text { Positive for S-100, Olig2 and } \\
\text { GFAP with immunohistochemical } \\
\text { stain }\end{array}$ & Lee et al. 2006 [54] \\
\hline 40 & M & American & $\begin{array}{l}\text { ODG, grade II early, } \\
\text { later } \mathrm{AO} \text {, grade III }\end{array}$ & 15 & $\begin{array}{l}\text { Pleura, bone, lungs, adrenal } \\
\text { gland, chest, liver, abdomen }\end{array}$ & 62 & 31 & Codeletion of $1 p / 19 q$ & Bruggers et al. 2007 [55] \\
\hline 41 & $\mathrm{~F}$ & Japanese & $\mathrm{AO}$, grade III & 17 & $\begin{array}{l}\text { Spleen, liver, pancreas, bone, } \\
\text { spinal dura mater, dorsal } \\
\text { root ganglia, lungs, lymph } \\
\text { nodes, iliopsoas muscle }\end{array}$ & 144 & 3 & $\begin{array}{l}\text { Markedly positive for Ki-67, } \\
\text { and positive for Olig2 with } \\
\text { immunohistochemical stain, }\end{array}$ & Uzuka et al. 2007 [56] \\
\hline 42 & $\mathrm{~F}$ & Korean & $\mathrm{AO}$, grade III & 48 & Liver, lungs & 28 & 27 & Not presented & Han et al. 2008 [4] \\
\hline 43 & M & Italian & $\mathrm{AO}$, grade III & 40 & Bone, bone marrow, liver & 10 & 5 & Not presented & Zustovich et al. 2008 [57] \\
\hline
\end{tabular}


Table 2 Review from the literature of 61 reported patients with oligodendroglioma with metastases outside the CNS (Continued)

\begin{tabular}{|c|c|c|c|c|c|c|c|c|c|}
\hline 44 & $\mathrm{~F}$ & Slovenian & $\mathrm{AO}$, grade III & 54 & $\begin{array}{l}\text { Cervical and neck lymph } \\
\text { nodes }\end{array}$ & 48 & 12 & $\begin{array}{l}\text { Positive for S-100, and GFAP } \\
\text { with immunohistochemical stain }\end{array}$ & Volavsek et al. 2009 [58] \\
\hline 45 & $\mathrm{~F}$ & Slovenian & AOA, grade III & 30 & Bone & $58+$ & 17 & $\begin{array}{l}\text { Positive for GFAP with } \\
\text { immunohistochemical stain }\end{array}$ & \\
\hline 46 & M & Japanese & $\mathrm{AO}$, grade III & 53 & $\begin{array}{l}\text { Lymph nodes, bone, spinal } \\
\text { dura mater, thymus gland, } \\
\text { chest wall }\end{array}$ & 30 & 24 & Codeletion of $1 p / 19 q$ & Noshita N, et al. 2010 [59] \\
\hline 47 & $\mathrm{~F}$ & Japanese & $\mathrm{AO}$, grade III & 73 & Cervical lesion & $18+$ & 18 & * & Oshiro S, et al. 2010 [60] \\
\hline 48 & M & Dutch & $\mathrm{AO}$, grade III & 59 & Bone marrow & 33 & 31 & $\begin{array}{l}\text { Codeletion of } 1 p / 19 q \text {, positive } \\
\text { for } S-100 \text {, and } p 53 \text { with } \\
\text { immunohistochemical stain }\end{array}$ & Krijnen JL, et al. 2010 [61] \\
\hline 49 & M & Dutch & ${ }^{*} \mathrm{ODG},{ }^{*}$ grade & 24 & Bone marrow & * & 84 & Not presented & \\
\hline 50 & M & Dutch & $\mathrm{AO}$, grade III & 34 & $\begin{array}{l}\text { Cervical lymph nodes, iliopsoas } \\
\text { muscle }\end{array}$ & * & not presented & Not presented & \\
\hline 51 & M & Dutch & $\mathrm{AO}$, grade III & 64 & Axillary lymph nodes & * & 34 & Not presented & \\
\hline 52 & M & Dutch & $\mathrm{AO}$, grade III & 72 & Bone marrow & * & 6 & Not presented & \\
\hline 53 & $\mathrm{~F}$ & Dutch & ${ }^{*} \mathrm{ODG},{ }^{*}$ grade & 67 & Bone marrow & * & 29 & Not presented & \\
\hline 54 & M & Dutch & $\mathrm{AO}$, grade III & 62 & Retroperitoneal lymph nodes & * & 21 & Not presented & \\
\hline 55 & M & Turkish & $\mathrm{AO}$, grade III & 55 & Bone marrow & $23+$ & 11 & $\begin{array}{l}\text { Positive for GFAP with } \\
\text { immunohistochemical stain }\end{array}$ & Kural C, et al. 2011 [62] \\
\hline 56 & M & Chinese & $\mathrm{AO}$, grade $I I I$ & 37 & Bone & $58+$ & 37 & $\begin{array}{l}\text { Positive for S-100, and GFAP } \\
\text { with immunohistochemical } \\
\text { stain }\end{array}$ & Wu Y, et al. 2011 [63] \\
\hline 57 & M & Italian & $\mathrm{AO}$, grade III & 40 & Bone marrow & 61 & 57 & $\begin{array}{l}\text { Positive for enolase, and GFAP } \\
\text { with immunohistochemical } \\
\text { stain }\end{array}$ & $\begin{array}{l}\text { Cordiano V, et al. } \\
2012[64]\end{array}$ \\
\hline 58 & $\mathrm{~F}$ & Turkish & $\mathrm{ODG},{ }^{*}$ grade & * & Cervical lymphatic chain & * & 60 & Codeletion of $1 p / 19 q$ & Can B, et al. 2012 [65] \\
\hline 59 & M & Turkish & $\mathrm{AO}$, grade III & 58 & Breast & * & * & * & $\begin{array}{l}\text { Alacacioglu A, et al. } \\
2012 \text { [66] }\end{array}$ \\
\hline 60 & M & Irish & $\mathrm{AO}$, grade III & 58 & Bone & $120+$ & 108 & $\begin{array}{l}\text { Codeletion of } 1 p / 19 q, \\
\text { positive for GFAP with } \\
\text { immunohistochemical stain }\end{array}$ & Greene J, et al. 2013 [67] \\
\hline 61 & M & Chinese & $\mathrm{AO}$, grade III & 45 & $\begin{array}{l}\text { Bone, bone marrow, lymph } \\
\text { nodes }\end{array}$ & 16 & 13 & $\begin{array}{l}\text { No deletion of } 1 \mathrm{p} / 19 \mathrm{q}, \text { PTEN } \\
\text { mutation in exon } 2, \text { MGMT } \\
\text { promoter methylated, positive } \\
\text { for IDH1, Ki-67, Olig2, and GFAP, } \\
\text { negative for MGMT, EMA and } \\
\text { Vim with immunohistochemical } \\
\text { stain }\end{array}$ & Present case \\
\hline
\end{tabular}

stain 
Table 3 Clinical features of 61 patients with extracranial metastatic oligodendrogliomas

\begin{tabular}{|c|c|c|}
\hline & Cases & Rate \\
\hline \multicolumn{3}{|l|}{ Gender } \\
\hline Total & 61 & \\
\hline Male & 33 & $54.1 \%(33 / 61)$ \\
\hline Female & 17 & $27.9 \%(16 / 61)$ \\
\hline Not given & 11 & $18.0 \%(11 / 61)$ \\
\hline \multicolumn{3}{|l|}{ Subjects } \\
\hline Total & 61 & \\
\hline Asian & 10 & $16.4 \%(10 / 61)$ \\
\hline European & 30 & $49.2 \%(30 / 61)$ \\
\hline American \& Canadian & 18 & $29.5 \%(18 / 61)$ \\
\hline Not given & 3 & $4.9 \%(3 / 61)$ \\
\hline \multicolumn{3}{|l|}{ Location of metastasis } \\
\hline Total Sites & 110 & \\
\hline Bone/bone marrow & 47 & $42.7 \%(47 / 110)$ \\
\hline Lymph node & 22 & $20.0 \%(22 / 110)$ \\
\hline Liver & 7 & $6.4 \%(7 / 110)$ \\
\hline Scalp & 6 & $5.5 \%(6 / 110)$ \\
\hline Lung & 6 & $5.5 \%(6 / 110)$ \\
\hline Pleura & 4 & $3.6 \%(4 / 110)$ \\
\hline Chest wall & 3 & $2.7 \%(3 / 110)$ \\
\hline Iliopsoas muscle & 2 & $1.8 \%(2 / 110)$ \\
\hline Soft tissue & 2 & $1.8 \%(2 / 110)$ \\
\hline Parotid gland & 2 & $1.8 \%(2 / 110)$ \\
\hline Other & 9 & \\
\hline Adrenal & 1 & $0.9 \%(1 / 110)$ \\
\hline Spleen & 1 & $0.9 \%(1 / 109)$ \\
\hline Thoracic wall & 1 & $0.9 \%(1 / 110)$ \\
\hline Pancreas & 1 & $0.9 \%(1 / 110)$ \\
\hline Dorsal root ganglia & 1 & $0.9 \%(1 / 110)$ \\
\hline Abdomen & 1 & $0.9 \%(1 / 110)$ \\
\hline Spinal dura mater & 1 & $0.9 \%(1 / 110)$ \\
\hline Breast & 1 & $0.9 \%(1 / 110)$ \\
\hline Thymus gland & 1 & $0.9 \%(1 / 109)$ \\
\hline
\end{tabular}

fluid to outside spaces [72]. Prolonged survival might also raise the risk of extracranial metastases. Thus, in our present case, craniotomy could be considered an influencing factor in extracranial metastasis.

The median age of the 60 patients found through the literature review was 40.0 years (range 3.5-73.0 y; Table 2). The overall survival ranged from 3-288 months, with a median of 38 months. These data are consistent with the recent reports of AOs $[57,63]$. The survival time of our patient was relatively shorter than the median, although he was given the standard regimen recommended by the
National Comprehensive Cancer Net (NCCN) guidelines [73]. His shorter survival and poor prognosis may be due, firstly, to the presence of $1 \mathrm{p} / 19 \mathrm{q}$, which may have adversely influenced the success of the recommended comprehensive therapy, as combined deletion of the $1 \mathrm{p}$ and $19 \mathrm{q}$ chromosomal arms is expected in OGD [74]. Molecular studies have revealed that deletions of chromosome $1 p$ and $19 q$ are usually associated with longer survival in OGD, as well as a better response to irradiation and chemotherapy. Tumors with such a co-deletion are sensitive to comprehensive therapy, with $90-100 \%$ of patients responding [74,75]. The overall survival for AOs is about 2-3 years for those without the $1 \mathrm{p} / 19 \mathrm{q}$ codeletion, compared with 6-7 years in those with $1 p / 19 q$ loss [76,77]. For our patient, the previously resected tumors from the brain lesions, as well as the metastatic lesions, all had complete $1 p$ and $19 q$ chromosomes. Thus the lack of deletion of $1 \mathrm{p} / 19 \mathrm{q}$ may have led to a shorter survival time under comprehensive therapy.

A second contributing factor toward the poor prognosis of the present case is the presence of the PTEN mutation, which was shown in both brain lesions and extracranial metastases. This may have made the patient more prone to extracranial metastases. PTEN tumor suppressors are located on human chromosome 10q23.3, which contains nine exons and encodes a $47-\mathrm{kD}$ dual-specific protein phospholipid phosphatase with 403 amino acids [17]. PTEN mutations accompany nearly $50 \%$ of the cases with a $10 \mathrm{q}$ deletion, suggesting that there might be another progression-related target gene in this region [78]. PTEN mutations and $10 \mathrm{q}$ deletions are more common in AOs without $1 p$ and $19 q$ losses [79]. Infrequently AOs carry activating mutations in the PIK3CA gene [80]. PTEN mutations have also been studied for their involvement in the pathogenesis of a number of human malignancies, including glioma [80].

Different mutations in the PTEN locus, including frameshifts and missense mutations, have proved to be correlated with human cancers $[81,82]$. These could result in early termination of translation and immature gene products, and subsequently lead to complete loss of vigor. In most cases, mutations in PTEN were found to decrease phosphatase activity $[19,83]$. In the present study, our patient definitely had a substitution mutation in PTEN at exon 2 , which may have made him more prone to extracranial metastases.

It must also be noted that, although our patient underwent a chemotherapy regimen with TMZ, his condition nevertheless deteriorated more rapidly afterward. As known, AOs are chemosensitive neoplasms that respond to combined treatment with lomustine, vincristine and procarbazine (i.e., PCV therapy), with $60-70 \%$ of patients responding [84]. Studies have also shown that TMZ, the oral alkylating agent that inhibits DNA replication by 
methylating nucleotide bases, is active and particularly well tolerated in AO patients $[85,86]$. TMZ methylates guanines in DNA at the $\mathrm{O} 6$ position, leading to base-pair mismatch. The known O6- methylguanine (O6-MeG) lesion causes DNA double-strand breaks and subsequent cell death through autophagy, apoptosis, or both [87]. MGMT is the DNA repair enzyme that repairs the O6MeG lesion and is induced either by chemotherapeutic agents or environmental carcinogens. Methylation of the MGMT promoter or high levels of MGMT are thought to be associated with resistance to TMZ [88]. Levin et al. [86] reported that TMZ was active in patients with progressive OGDs, and that a $1 \mathrm{p}$ deletion and low MGMT protein expression could contribute to a better response to TMZ treatment. For our patient, results of the MSP-PCR assays of the primary brain lesions and autopsied metastatic tissues all showed the methylated MGMT promoter. However, we regret that although several cycles of chemotherapy of TMZ were given, the patient still deteriorated rapidly and eventually succumbed. The reasons for his failure to respond favorably to TMZ chemotherapy remain to be explored.

\section{Conclusions}

In summary, extracranial metastases in $\mathrm{AO}$ do occur, although they are very rare. Detection of molecular markers such as combined deletion of the $1 \mathrm{p}$ and $19 \mathrm{q}$ chromosomal arms, hypermethylation of the MGMT promoter, and PTEN exon mutations may help elucidate which subtypes of AO are more prone to extracranial metastases, which would benefit these patients.

\section{Consent}

Written informed consent was obtained from the patient's family for publication of this Case Report and any accompanying images. A copy of the written consent is available for review by the Editor-in-Chief of this journal.

\section{Abbreviations}

OGD: Oligodendrogliomas; MRI: Magnetic resonance imaging; MGMT: O-6-methylguanine-DNA methyltransferase; PTEN: Phosphatase and tensin homolog; CNS: Central nervous system; AO: Anaplastic oligodendroglioma; WHO: World Health Organization; PET-CT: Positron emission tomography-computed tomography; EDTA: Ethylenediaminetetraacetic acid; IDH1: Isocitrate dehydrogenase-1; GFAP: Glial fibrillary acidic protein; EMA: Epithelial membrane antigen; MS-PCR: Methylation-specific polymerase chain reaction; PCR-SSCP: PCR single-strand conformation polymorphism; FISH: Fluorescent in situ hybridization; NCCN: National comprehensive cancer net.
}

\section{Competing interests}

The authors declare that they have no competing interest.

\section{Authors' contributions}

YZ and GG designed the study. GL, ZZ, SH and GC participated in designing and coordinating the study, and GL drafted the manuscript. ZZ and TJ worked together to draft the manuscript. JZ, HL, LG and HY participated in following up the patient, reviewing the relevant articles, and helped to improve the manuscript. All authors have read and approved the final manuscript.

\section{Acknowledgments}

This work is supported in part by grants from the National Natural Science Foundation of China (No. 81272776 and No. 81272419), China Postdoctoral Science Foundation (No. 20100471628 and No. 201104634), Wu Jieping Medical Foundation (320.6750.12161), Shaanxi Province Programs of Science and Technology Development (No. 2012 K 13-01-13 and 2011 K12-47), the Innovation Project 2012, and the Talents Program 2010 \& 2013 of Tangdu Hospital, Fourth Military Medical University. We thank all the clinicians and hospital staff for help in the collection of samples and data for this study. Additionally, we thank Prof. Dr. Qing Li, Department of Pathology, Fourth Military Medical University, and Prof. Dr. Xue-jun Yang, Department of Pathology of General Hospital, Tianjin Medical University, for sharing their experiences with primary CNS tumors.

\section{Author details}

${ }^{1}$ Department of Neurosurgery, Tangdu Hospital, Fourth Military Medical University, Xi'an 710038, P.R China. ${ }^{2}$ National Engineering Research Center for Miniaturized Detection Systems, School of Life Sciences, Northwest University, Xi'an 710069, P.R China. ${ }^{3}$ Department of Pathology, Tangdu Hospital, Fourth Military Medical University, Xi'an 710038, P.R China. ${ }^{4}$ Department of Radiology, Tangdu Hospital, Fourth Military Medical University, Xi'an 710038, P.R China. ${ }^{5}$ Department of Administrative, Tangdu Hospital, Fourth Military Medical University, Xi'an 710038, P.R. China.

Received: 1 December 2013 Accepted: 31 December 2013

Published: 21 January 2014

\section{References}

1. Bailey P, Cushing P: A Classification of the Tumors of the Glioma Group on Histogenetic Basis with Correlated Study of Prognosis. Philadelphia: J.B. Lippincott; 1926:175.

2. Smith DR, Hardman JM, Earle KM: Metastasizing neuroectodermal tumors of the central nervous system. J Neurosurg 1969, 31:50-58.

3. Liwnicz BH, Rubinstein LJ: The pathways of extraneural spread in metastasizing gliomas: a report of three cases and critical review of the literature. Hum Pathol 1979, 10:453-467.

4. Han SR, Yoon SW, Yee GT, Choi CY, Lee DJ, Sohn MJ, Chang SH, Whang CJ: Extraneural metastases of anaplastic oligodendroglioma. J Clin Neurosci 2008, 15:946-949.

5. McLendon RE, Bentley RC, Parisi JE, Tien RD, Harrison JC, Tarbell NJ, Billitt AL, Gualtieri RJ, Friedman HS: Malignant supratentorial glial-neuronal neoplasms: report of two cases and review of the literature. Arch Pathol Lab Med 1997, 121:485-492.

6. Tatar Z, Thivat E, Planchat E, Gimbergues P, Gadea E, Abrial C, Durando X: Temozolomide and unusual indications: review of literature. Cancer Treat Rev 2013, 39:125-135.

7. Louis DN, Ohgaki H, Wiestler OD, Cavenee WK, Burger PC, Jouvet A, Scheithauer BW, Kleihues P: The 2007 WHO classification of tumours of the central nervous system. Acta Neuropathol 2007, 114:97-109.

8. Giannini C, Scheithauer BW, Weaver AL, Burger PC, Kros JM, Mork S, Graeber MB, Bauserman S, Buckner JC, Burton J, Riepe R, Tazelaar HD, Nascimento AG, Crotty T, Keeney GL, Pemicone P, Altermatt H: Oligodendrogliomas: reproducibility and prognostic value of histologic diagnosis and grading. J Neuropathol Exp Neurol 2001, 60:248-282.

9. Stupp R, Hegi ME, Mason WP, van den Bent MJ, Taphoorn MJ, Janzer RC, Ludwin SK, Allgeier A, Fisher B, Belanger K, Hau P, Brandes AA, Gijtenbeek J, Marosi C, Vecht CJ, Mokhtari K, Wesseling P, Villa S, Eisenhauer E, Gorlia T, Weller M, Lacombe D, Cairncross JG, Mirimanoff RO: European Organisation for Research and Treatment of Cancer Brain Tumour and Radiation Oncology Groups; National Cancer Institute of Canada Clinical Trials Group: effects of radiotherapy with concomitant and adjuvant temozolomide versus radiotherapy alone on survival in glioblastoma in a randomised phase III study: 5-year analysis of the EORTC-NCIC trial. Lancet Oncol 2009, 10:459-466.

10. Hegi ME, Liu L, Herman JG, Stupp R, Wick W, Weller M, Mehta MP, Gilbert MR: Correlation of O6-methylguanine methyltransferase (MGMT) promoter methylation with clinical outcomes in glioblastoma and clinical strategies to modulate MGMT activity. J Clin Oncol 2008, 26:4189-4199.

11. Reineke $T$, Jenni $B, A$ bdou MT, Frigerio S, Zubler $P$, Moch $H$, Tinguely M: Ultrasonic decalcification offers new perspectives for rapid FISH, DNA, and RT-PCR analysis in bone marrow trephines. Am J Surg Pathol 2006, 30:892-896 
12. Mehdi SJ, Alam MS, Batra S, Rizvi MMA: Allelic loss at 6q25-27, the Parkin tumor suppressor gene locus in cervical carcinoma. Med Oncol 2011, 28:1520-1526

13. Sambrook J, Russell DW: Molecular cloning: A laboratory manual. 3rd edition. Cold Spring Harbor Lab. Press: Cold Spring Harbor; 2001.

14. Dong Z, Pang JS, Ng MH, Poon WS, Zhou L, Ng HK: Identification of two contiguous minimally deleted regions on chromosome 1 p36.31-p36.32 in oligodendroglial tumors. Br J Cancer 2004, 91:1105-1111.

15. Hegi ME, Diserens AC, Gorlia T, Hamou MF, de Tribolet N, Weller M, Kros JM, Hainfellner JA, Mason W, Mariani L, Bromberg JE, Hau P, Mirimanoff RO, Cairncross JG, Janzer RC, Stupp R: MGMT gene silencing and benefit from temozolomide in glioblastoma. N Engl J Med 2005, 352:997-1003.

16. Eng C: PTEN: one gene, many syndromes. Hum Mutat 2003, 22:183-198.

17. Zheng H, Takahashi H, Murai Y, Cui Z, Nomoto K, Tsuneyama K, Takano Y: Low expression of FHIT and PTEN correlates with malignancy of gastric carcinomas: tissue-array findings. Appl Immunohistochem Mol Morphol 2007, 15:432-440.

18. Ali A, Saluja SS, Hajela K, Mishra PK, Rizvi MA: Mutational and expressional analyses of PTEN gene in colorectal cancer from Northern India. Mol Carcinog 2013. 10.1002/mc.22001. [Epub ahead of print].

19. Rizvi MA, Shabbir MA, Ali A, Mehdi SJ, Batra S, Mandal AK: Aberrant promoter methylation and inactivation of PTEN gene in cervical carcinoma from Indian population. J Cancer Res Clin Oncol 2011, 137:1255-1262.

20. Guo CY, XU XF, Wu JY, Liu SF: PCR-SSCP-DNA sequencing method in detecting PTEN gene mutation and its significance in human gastric cancer. World J Gastroenterol 2008, 14:3804-3811.

21. Garner J, Morcos Y, Bari M: Extradural cord compression due to metastatic oligodendroglioma. J Neurooncol 2002, 58:71-75.

22. Subramanian A, Harris A, Piggott K, Shieff C, Bradford R: Metastasis to and from the central nervous system: the 'relatively protected site'. Lancet Oncol 2002, 3:498-507

23. Al-Ali F, Hendon AJ, Liepman MK, Wisniewski JL, Krinock MJ, Beckman K: Oligodendroglioma metastatic to bone marrow. AJNR Am J Neuroradiol 2005, 26:2410-2414

24. Fayeye O, Sankaran V, Sherlala K, Choksey M: Oligodendroglioma presenting with intradural spinal metastases: an unusual cause of cauda equine syndrome. J Clin Neurosci 2010, 17:265-267.

25. Shaw EG, Scheithauer BW, O'Fallon JR, Tazelaar HD, Davis DH: Oligodendrogliomas: the Mayo Clinic experience. J Neurosurg 1992, 76:428-434.

26. James TGl, Pagel W: Oligodenroglioma with extracranial metastases. Br J Surg 1951, 39:56-65.

27. Spataro J, Sacks O: Oligodendroglioma with remote metastases. Case report. J Neurosurg 1968, 28:373-379.

28. Jellinger K, Minauf M, Salzer-Kuntschik M: Oligodendroglioma with extraneural metastases. J Neurol Neurosurg Psychiatry 1969, 32:249-253.

29. Schuster $\mathrm{H}$, Jellinger $\mathrm{K}$, Gund $\mathrm{A}$, Regele H: Extracranial metastases of anaplastic cerebral gliomas. Acta Neurochir (Wien) 1976, 35:247-259.

30. Kernohan JW: Oligodendrogliomas. In Minckler J (ed) Pathology of the nervous system. Vol 2nd edition. New York: McGraw-Hill Co; 1971. 1993-2007.

31. Eade OE, Urich H: Metastasising gliomas in young subjects. J Pathol 1971 103:245-256.

32. Cappalaere P, Clay A, Adenis L, Demaille A, Laine E: Les metastases des tumors cerebrales primitives en dehors du nevraxe: a propos de trios observations. Bull Cancer (Paris) 1972, 59:235-254.

33. Brander WL, Turner DR: Extracranial metastases from a glioma in the absence of surgical intervention. J Neurol Neurosurg Psychiatry 1975, 38:1133-1135.

34. Kummer RV, Volk B, Dorndorf W: Extraneural metastasierendes oligodendrogliom. Arch Psychiatr Nervenkr 1969, 223:287-293.

35. Chin HW, Hazel JJ, Kim TH, Webster JH: Oligodendrogliomas. I. A clinical study of cerebral oligodendrogliomas. Cancer 1980, 45:1458-1466.

36. Ordonez NG, Ayala AA, Leavens ME: Extracranial metastases of oligodenroglioma: report of a case and review of the literature. Neurosurgery 1981, 8:391-395. comments 395-396.

37. Nakamura $O$, Watanabe T, Nomura K, Nakajima T: Diffuse bone marrow metastasis of an anaplastic oligodendroglioma. No Shinkei Geka 1985, 13:903-909.

38. Newman HFV, Howard GCV, Reid PM: Metastatic oligodendroglioma presenting as a leukoerythroblastic anaemia. Eur J Surg Onc 1985 $11: 287-288$
39. Macdonald DR, O'Brien RA, Gilbert JJ, Cairncross JG: Metastatic anaplastic oligodendroglioma. Neurology 1989, 39:1593-1596.

40. Rolski J, Rzepecki W, Kałuza J, Zemełka T, Zuchowska-Vogelgesang B: A rare case of dissemination of anaplastic oligodendroma outside the central nervous system. Neurol Neurochir Pol 1993, 27:93-97.

41. Steininger $H$, von Streitberg U: Oligodendroglioma with cervical lymph node metastasis. Pathologe 1993, 14:386-390.

42. Gerrard GE, Bond MG, Jack AS: Bone marrow infiltration by a parietal lobe grade III oligodendroglioma. Clin Oncol (R Coll Radiol) 1995, 7:321-322.

43. Schröder R, Lorenzen J, Ostertag H, Ortmann M, Hansmann ML: Extraneural metastasis of brain and spinal cord tumors. Report of 2 cases. Pathologe 1995, 16:223-229.

44. Monzani V, Rovellini A, Masini B, Cappricci E, Miserocchi G: Metastatic oligodendroglioma. Case report. J Neurol Sci 1996, 40:239-241.

45. Dawson TP: Case report. Pancytopenia from a disseminated anaplastic oligodendroglioma. Neuropathol App Neurobiol 1997, 23:516-520.

46. Finsterer J, Breiteneder S, Mueller MR, Wogritsch C, Vesely M, Kleinert R, Pendl G, Mamoli B: Pleural and bone marrow metastasis from supratentorial oligoastrocytoma grade III. Oncology 1998, 55:345-348.

47. Anand M, Kumar R, Jain P, Gupta R, Ghosal N, Sharma A, Agarwal A, Sharma MC: Metastatic anaplastic oligodendroglioma simulating acute leukaemia. Acta Cytol 2003, 47:467-469.

48. Giordana MT, Gasverde S, Balteri I: Bone metastasis of oligodendrogliomas: clinical and molecular genetic study. Neuro Oncol 2002, 4:38e.

49. Sharma A, Agarwal A, Sharma MC, Anand M, Agarwal S, Raina V: Bone marrow metastasis in anaplastic oligodendroglioma. Int J Clin Pract 2003 57:351-352

50. Choon A, Roepke JE: Importance of immunohistochemichal staining in metastatic anaplastic oligodendroglioma. Arch Pathol Lab Med 2004, 128:489-490.

51. Morrison T, Bilbao JM, Yang G, Perry JR: Bony metastases of anaplastic oligodendroglioma respond to temozolomide. Can J Neurol Sci 2004, 31:102-108

52. Wang M, Murphy KM, Kulesza P, Hatanpaa KJ, Olivi A, Tufaro A, Erozan Y, Westra WH, Burger PC, Berg KD: Molecular diagnosis of metastasizing oligodendroglioma: a case report. J Mol Diagn 2004, 6:52-57.

53. Merrell R, Nabors LB, Perry A, Palmer CA: 1p/19q chromosome deletions in metastatic oligodendroglioma. J Neurooncol 2006, 80:203-207.

54. Lee CC, Jiang JS, Chen ET, Yokoo H, Pan YH, Tsai MD: Cytologic diagnosis of a metastatic oligodendroglioma in a pleural effusion. A case report. Acta Cytol 2006, 50:542-544.

55. Bruggers $C$, White $K$, Zhou H, Chen Z: Extracranial relapse of an anaplastic oligodendroglioma in an adolescent: case report and review of the literature. J Pediatr Hematol Oncol 2007, 29:319-322.

56. Uzuka T, Kakita A, Inenaga C, Takahashi H, Tanaka R, Takahashi H: Frontal anaplastic oligodendroglioma showing multi-organ metastases after a long clinical course. Case report. Neurol Med Chir (Tokyo) 2007, 47:174-177

57. Zustovich F, Della Puppa A, Scienza R, Anselmi P, Furlan C, Cartei G: Metastatic oligodendrogliomas: a review of the literature and case report. Acta Neurochir (Wien) 2008, 150:699-702. discussion 702-703.

58. Volavsek M, Lamovec J, Popović M: Extraneural metastases of anaplastic oligodendroglial tumors. Pathol Res Pract 2009, 205:502-507.

59. Noshita N, Mashiyama S, Fukawa O, Asano S, Watanabe M, Tominaga T: Extracranial metastasis of anaplastic oligodendroglioma with $1 \mathrm{p} 19 \mathrm{q}$ loss of heterozygosity-case report. Neurol Med Chir (Tokyo) 2010, 50:161-164.

60. Oshiro S, Komatsu F, Tsugu H, Nabeshima K, Abe H, Ohkawa M, Inoue T: A case of intramedullary cervical metastasis from cerebellar anaplastic oligodendroglioma without typical MR appearance for CSF dissemination. No Shinkei Geka 2010, 38:279-285.

61. Krijnen JL, Fleischeur RE, van Berkel M, Westenend PJ: Metastatic oligodendroglioma: a case report and incidence in The Netherlands. Clin Neuropathol 2010, 29:141-146.

62. Kural C, Pusat $\mathrm{S}$, Sentürk $T$, Seçer Hil, Izci Y: Extracranial metastases of anaplastic oligodendroglioma. J Clin Neurosci 2011, 18:136-138.

63. Wu Y, Liu B, Qu L, Tao H: Extracranial skeletal metastasis in anaplastic oligodendroglioma: case report and review of the literature. J Int Med Res 2011, 39:960-967.

64. Cordiano V, Miserocchi F, Storti M: Bone marrow metastases from anaplastic oligodendroglioma presenting with pancytopenia and hypogammaglobulinemia: a case report. Tumori 2011, 97:808-811. 
65. Can B, Akpolat I, Meydan D, Üner A, Kandemir B, Söylemezoğlu F: Fine-needle aspiration cytology of metastatic oligodendroglioma: case report and literature review. Acta Cytol 2012, 56:97-103.

66. Alacacioglu A, Unal S, Canpolat S, Yurt A, Oztekin O, Coskun A, Karatas A Postaci H, Sop G: Breast metastasis of anaplastic oligodendroglioma: a case report. Tumori 2012, 98:162e-164e.

67. Greene J, Cadoo K, Ti J, O’Donnell N, Allcutt D, Farrell M, Grogan L: 1p19q co-deleted oligodendroglioma metastatic to bone. Clin Neuropathol 2013, 32:139-141.

68. Gyepes MT, D’ angio GJ: Extracranial metastases from central nervous system tumors in children and adolescents. Radiology 1966, 87:55-63.

69. Carlsen JG, Tietze A, Lassen YA, Rosendal F: Paraplegia due to drop metastases from anaplastic oligodendroglioma. Br J Neurosurg 2012, 26:94-95.

70. Schweitzer $T$, Vince $G H$, Herbold C, Roosen K, Tonn JC: Extraneural metastases of primary brain tumors. J Neurooncol 2001, 53:107-114.

71. Hoffman HJ, Duffner PK: Extraneural metastases of central nervous system tumors. Cancer 1985, 56:1778-1782.

72. Mechtler LL, Nandigam K: Spinal cord tumors: new views and future directions. Neurol Clin 2013, 31:241-268

73. NCCN Clinical Practice Guidelines in Oncology: Central Nervous System Cancers. Version1; 2013. http://www.nccn.org/professionals/physician_ gls/pdf/cns.pdf.

74. Cairncross JG, Ueki K, Zlatescu C, Lisle DK, Finkelstein DM, Hammond RR, Silver JS, Stark PC, Macdonald DR, Ino Y, Ramsay DA, Louis DN: Specific genetic predictors of chemotherapeutic response and survival in patients with anaplastic oligodendroglioma. J Natl Cancer Inst 1998, 90:1473-1479.

75. Smith JS, Perry A, Borell TJ, Lee HK, O'Fallon J, Hosek SM, Kimmel D, Yates A, Burger PC, Scheithauer BW, Jenkins RB: Alterations of chromosome arms 1p and $19 q$ as predictors of survival in oligodendrogliomas, astrocytomas, and mixed oligoastrocytomas. J Clin Oncol 2000, 18:636-645.

76. Davis FG, McCarthy BJ, Freels S, Kupelian V, Bondy ML: The conditional probability of survival of patients with primary malignant brain tumors: surveillance, epidemiology, and end results (SEER) data. Cancer 1999, 85:485-491.

77. Scott CB, Scarantino C, Urtasun R, Movsas B, Jones CU, Simpson JR, Fischbach AJ, Curran WJ Jr: Validation and predictive power of Radiation Therapy Oncology Group (RTOG) recursive partitioning analysis classes for malignant glioma patients: a report using RTOG 90-06. Int J Radiat Oncol Biol Phys 1998, 40:51-55.

78. Broderick DK, Di C, Parrett TJ, Samuels YR, Cummins JM, McLendon RE, Fults DW, Velculescu VE, Bigner DD, Yan H: Mutations of PIK3CA in anaplastic oligodendrogliomas, high-grade astrocytomas, and medulloblastomas. Cancer Res 2004, 64:5048-5050.

79. Ino Y, Betensky RA, Zlatescu MC, Sasaki H, Macdonald DR, Stemmer-Rachamimov AO, Ramsay DA, Cairncross JG, Louis DN: Molecular subtypes of anaplastic oligodendroglioma: implications for patient management at diagnosis. Clin Cancer Res 2001, 7:839-845.

80. Yang Y, Shao N, Luo G, Li L, Zheng L, Nilsson-Ehle PXN: Mutations of PTEN gene in gliomas correlate to tumor differentiation and short-term survival rate. Anticancer Res 2010, 30:981-985.

81. Wang JY, Huang TJ, Chen FM, Hsieh MC, Lin SR, Hou MF, Hsieh JS: Mutation analysis of the putative tumor suppressor gene PTEN/MMAC1 in advanced gastric carcinomas. Virchows Arch 2003, 442:437-443.

82. Tate G, Suzuki T, Mitsuya T: Mutation of the PTEN gene in a human hepatic angiosarcoma. Cancer Genet Cytogenet 2007, 178:160-162.

83. Rizvi MM, Ali A, Mehdi SJ, Saluja SS, Mishra PK: Association of epigenetic alteration in PTEN gene with colorectal cancer progression among Indian population. Int J Colorectal Dis 2013, 28:283-284.

84. van den Bent MJ, Taphoorn MJ, Brandes AA, Menten J, Stupp R, Frenay M, Chinot O, Kros JM, van der Rijt CC, Vecht CJ, Allgeier A, Gorlia T: European Organization for Research and Treatment of Cancer Brain Tumor Group: Phase II study of first-line chemotherapy with temozolomide in recurrent oligodendroglial tumors: the European Organization for Research and Treatment of Cancer Brain Tumor Group Study 26971. J Clin Oncol 2003, 21:2525-2528

85. Hoang-Xuan K, Capelle L, Kujas M, Taillibert S, Duffau H, Lejeune J, Polivka $M$, Crinière $E$, Marie $Y$, Mokhtari $K$, Carpentier AF, Laigle F, Simon JM, Cornu $P$, Broët $P$, Sanson M, Delattre JY: Temozolomide as initial treatment for adults with low-grade oligodendrogliomas or oligoastrocytomas and correlation with chromosome 1p deletions. J Clin Oncol 2004, 22:3133-3138.
86. Levin N, Lavon I, Zelikovitsh B, Fuchs D, Bokstein F, Fellig Y, Siegal T: Progressive low-grade oligodendrogliomas: response to temozolomide and correlation between genetic profile and 06- methylguanine DNA methyltransferase protein expression. Cancer 2006, 106:1759-1765.

87. Ziegler DS, Kung AL, Kieran MW: Antiapoptosis mechanisms in malignant gliomas. J Clin Oncol 2008, 26:493-500.

88. Kesari S, Schiff D, Drappatz J, LaFrankie D, Doherty L, Macklin EA, Muzikansky A, Santagata S, Ligon KL, Norden AD, Ciampa A, Bradshaw J, Levy B, Radakovic G, Ramakrishna N, Black PM, Wen PY: Phase II study of protracted daily temozolomide for lowgrade gliomas in adults. Clin Cancer Res 2009, 15:330-337.

doi:10.1186/1746-1596-9-17

Cite this article as: Li et al:: Occipital anaplastic oligodendroglioma with multiple organ metastases after a short clinical course: a case report and literature review. Diagnostic Pathology 2014 9:17.

\section{Submit your next manuscript to BioMed Central and take full advantage of:}

- Convenient online submission

- Thorough peer review

- No space constraints or color figure charges

- Immediate publication on acceptance

- Inclusion in PubMed, CAS, Scopus and Google Scholar

- Research which is freely available for redistribution

Submit your manuscript at www.biomedcentral.com/submit
C) Biomed Central 